\title{
PERUBAHAN KEKUATAN KOMPRESI DENTAL PLASTER YANG DICAMPUR DENGAN NACI DALAM BERBAGAI VARIASI KONSENTRASI
}

\author{
${ }^{1}$ Ishak Yan Aipipidely \\ ${ }^{2}$ Vonny N. S. Wowor \\ ${ }^{3}$ Jimmy Abidjulu
}

\author{
${ }^{1}$ Kandidat Skripsi Program Studi Kedokteran Gigi Fakultas Kedokteran \\ Universitas Sam Ratulangi Manado \\ ${ }^{2}$ Bagian Ilmu Material Kedokteran Gigi Program Studi Kedokteran Gigi Fakultas Kedokteran \\ Universitas Sam Ratulangi Manado \\ Email: Ish4k99@yahoo.com
}

\begin{abstract}
Dental plaster is a type of sedimentary rock formed from limestone and chemically dissolved sulfate in the soil to form calcium sulfate (CaSO4 ). Dental plaster of the natural compound is generally a stable form of CaSO4 $2 \mathrm{H} 2 \mathrm{O}$. Water contained in dental plaster water is not free but united by water molecules hence the nature of the universe is dental plaster is stable. If dental plaster hemihydrate reacts with water, the water molecules in the dental plaster back to the original amount. As a result of this reaction, the heat stored in dental plaster hemihydrate will be issued and the molecules of a separate dental plaster ( for burning ) reunite to form stable CaSO4 2H2O. This was an experimental study which aimed to test the compression strength of dental plaster mixed with $\mathrm{NaCl}$ in various concentrations. There were 3 samples to be tested. The results showed that at $0.5 \%$ concentration of $7.06 \mathrm{MPa}$, at $1 \% 6.90 \mathrm{MPa}$, at $1.5 \% 12.23 \mathrm{MPa}$, at $2 \% 10.06 \mathrm{MPa}$, at $3 \%$ 6.33 $\mathrm{MPa}$, at $4 \% 4.42 \mathrm{MPa}$, and at control $8.63 \mathrm{MPa}$. At the concentration of $1.5 \%$ as compared to the other concentrations, the use of electron - electron bound to each other from hemihydrate powder and the $\mathrm{NaCl}$ resulting in a stable chemical bonds that can increase the strengthness of compressed dental plaster mixed with $1.5 \% \mathrm{NaCl}$. Conclusion: Dental plaster mixed with $\mathrm{NaCl} 4 \%$ had the lowest strengthness while dental plaster mixed with $\mathrm{NaCl}$ 1.5\% had the highest strengthness.
\end{abstract}

Keywords: dental plaster, $\mathrm{NaCl}$, compression tools

Abstrak: Dental plaster merupakan jenis batuan endapan yang terbentuk secara kimiawi dari kapur dan sulfat yang larut dalam tanah membentuk calcium sulfat $\left(\mathrm{CaSO}_{4}\right)$, dental plaster yang dari alam umumnya merupakan senyawa stabil berbentuk CaSO4 $2 \mathrm{H}_{2} \mathrm{O}$. Air yang terkandung dalam dental plaster itu bukan berbentuk air bebas tetapi air yang bersatu dengan molekulnya sehingga dental plaster alam bersifat stabil. Bila dental plaster hemihidrat bereaksi dengan air maka molekul air di dalam dental plaster kembali ke jumlah semula. Akibat reaksi ini, panas yang tersimpan dalam dental plaster hemihidrat akan dikeluarkan dan molekul-molekul dental plaster yang terpisah (karena pembakaran) bersatu kembali ke bentuk stabil $\mathrm{CaSO}_{4} 2 \mathrm{H}_{2} \mathrm{O}$. Penelitian ini merupakan penelitian eksperimental yang bertujuan untuk menguji kekuatan kompresi dental plaster yang dicampur dengan $\mathrm{NaCl}$ dalam berbagai variasi konsentrasi. Terdapat 3 sampel untuk diuji. Hasil penelitian menunjukkan bahwa pada konsentrasi $\mathrm{NaCl}$ 0,5\% kekuatan dental plaster 7,06 $\mathrm{MPa}$; $1 \%$ 6,90 MPa; 1,5\% 12,23 MPa; 2\% 10,06 MPa; 3\% 6,33 MPa; 4\% 4,42 MPa; dan kontrol 8,63 MPa. Hasil pada konsentrasi 1,5\% dibandingkan dengan kosentrasi lainya dikarenakan adanya pemakaian elektron-elektron yang saling terikat dari bubuk hemihidrat dan $\mathrm{NaCl}$ tersebut, sehingga terjadi ikatan-ikatan kimia stabil yang dapat menambah kekerasan atau 
kekuatan kompresi dari dental plaster tersebut saat dicampur dengan konsentrasi $\mathrm{NaCl}$ 1,5\%.

Simpulan: Campuran dental plaster dengan $\mathrm{NaCl} 4 \%$ memiliki kekuatan terendah sedangkan dengan $\mathrm{NaCl}$ 1,5\% memiliki kekuatan tertinggi.

Kata kunci: dental plaster, $\mathrm{NaCl}$, alat kompresi

Dental plaster ialah jenis batuan endapan yang terbentuk secara kimiawi dari kapur dan sulfat yang larut dalam tanah membentuk calcium sulfat $\left(\mathrm{CaSO}_{4}\right)$. Dental plaster yang berasal dari alam umumnya merupakan senyawa stabil berbentuk $\mathrm{CaSO} 4 \quad 2 \mathrm{H}_{2} \mathrm{O}$. Air yang terkandung dalam dental plaster itu bukan air bebas tetapi air yang bersatu dengan molekulnya sehingga sifat dari dental plaster alam adalah bersifat stabil. Akibat reaksi ini, panas yang tersimpan dalam dental plaster hemihidrat akan dikeluarkan dan molekul-molekul dental plaster yang terpisah (karena pembakaran) bersatu kembali ke bentuk stabil $\mathrm{CaSO}_{4} 2 \mathrm{H}_{2} \mathrm{O}$. Ini berarti dental plaster mengeras setelah diberi air dan dapat digunakan sebagai tujuan konstruksi atau sebagainya. Melalui suhu dan temperatur yang berbeda, dihasilkan dua jenis gipsum yaitu dental plaster dan dental stone.

Dalam hal ini, dental plaster banyak digunakan untuk berbagai keperluan pada bidang kedokteran gigi, contohnya untuk pembuatan basis model studi rahang, mold pada pembuatan protesa akrilik, dan lainlain. Untuk keperluan ini dibutuhkan bahan dental plaster yang mempunyai kekuatan kompresi yang tidak terlalu besar, dan bahan yang biasa digunakan yakni dental plaster. Kekuatan kompresi dari produk dental plaster tidak terlalu besar bila dibandingkan dengan dental stone. Hal ini disebabkan karena perbedaan bentuk partikel bubuk dari keduanya., $^{1,2}$ Kekuatan kompresi lebih besar yang dimiliki dental stone membuat gipsum ini dipilih untuk digunakan dalam pembuatan model rahang. Namun dalam praktek di klinik, operator seringkali dipersulit dengan habisnya persediaan dental stone saat akan melakukan pengecoran cetakan gigi. Pekerjaan pengecoran sering tidak dapat ditunda dikarenakan cetakan rahang tersebut tidak bisa dibiarkan teralu lama pada suhu kamar karena dapat menyebabkan terjadinya perubahan dimensi cetakan. Mengantisipasi kondisi demikian perlu dipikirkan adanya bahan alternatif pengganti.

Pada pengalaman klinik beberapa dokter ternyata dental plaster bisa digunakan untuk menggantikan peran dari dental stone, yakni dengan melakukan pencampuran atau penambahan garam dapur $(\mathrm{NaCl})$ sebagai bahan pencampur. $\mathrm{NaCl}$ selama ini jarang digunakan dibandingkan dengan jenis bahan 
pencampur lainnya. Pada umumnya $\mathrm{NaCl}$ digunakan dalam hal pekerjaan konstruksi. Pada konsentrasi yang rendah $\mathrm{NaCl}$ dapat mempercepat waktu pengerasan dental plaster sedangkan bila ditambahkan dalam jumlah yang tinggi maka dapat menjadi retarder $^{17}$. Adanya pengalaman tersebut mendorong peneliti untuk melakukan uji kekuatan kompresi pada dental plaster yang dicampur dengan $\mathrm{NaCl}$ dalam berbagai konsentrasi untuk melihat adanya perubahan kekuatan kompresi yang terjadi pada dental plaster. Penelitian ini

\section{METODE PENELITIAN}

Penelitian ini merupakan penelitian eksperimental laboratories, menggunakan rancangan penelitian eksperimental murni dengan desain rancangan eksperimental sederhana (post test control group design), dimana observasi dilakukan setelah pelakuan. Hasil penelitian ini akan menunjukkan perubahan kekuatan kompresi dental plaster yang dicampur dengan $\mathrm{NaCl}$ dalam berbagai konsentrasi. Penelitian dilakukan dengan meminta ijin pada kepala bagian Laboratorium Struktur dan Material Bangunan Fakultas Teknik Universitas Sam Ratulangi. Penelitian dilakukan dari bulan februari hingga Oktober 2013, penelitian dilakukan dengan cara membuat balok gipsum dari dental plaster, sampel yaitu balok gipsum yang dilakukan untuk mengetahui apakah terjadi tingkat perubahan kekuatan kompresi pada dental plaster setelah dicampur dengan $\mathrm{NaCl}$,serta pada konsentrasi berapa dapat mencapai kekuatan kompresi yang maksimal, tujuan penelitian untuk mengetahui apakah terjadi perubahan kekuatan kompresi,serta mengetahui konsentrasi berapa yang dapat memberikan kekuatan kompresi yang maksimal.

dibuat dari dental plaster yang dicampur dengan larutan $\mathrm{NaCl}$ dalam berbagi konsentrasi,sedangkan besarnya sampel yaitu 18 balok gipsum dengan variasi konsentrasi konsentrasi $\mathrm{NaCl}$ (0,5\%, 1\%, 1,5\%, $2 \%, 3 \%, 4 \%)$ terdiri dari 3 buah balok.Uji kekuatan kompresi balok gipsum merupakan pengujian dari kekuatan tekanan yang diberikan pada balok gipsum yang dibuat dari dental plaster dengan cara memecahkan sampel balok gipsum menggunakan alat uji kompresi. Cara kerja pembuatan larutan $\mathrm{NaCl}$ dalam berbagai konsentrasi:Konsentrasi $\quad \mathrm{NaCl} \quad 0,5 \%$ dibuat dengan cara melakukan pencampuran antara 0,5gr $\mathrm{NaCl}$ yang sudah ditimbang terlebih dahulu dengan aquades sebanyak $100 \mathrm{ml}$ dalam gelas ukur 
dimasukan ke dalam gelas ukur dan diaduk hingga larut. Selanjutnya dengan cara yang sama dibuat larutan dengan konsentrasi 1\%; 1,5\%; 2\%; 3\% dan 4\%. Balok gipsum dental plaster merupakan hasil pencampuran bubuk gipsum merek Super Type 6000 dengan $\mathrm{W}: \mathrm{P}$ ratio $100 \mathrm{ml}$ air berbanding 200gr bubuk gipsum sebagai variabel kontrol dan hasil pencampuran bubuk gipsum jenis yang sama dengan larutan $\mathrm{NaCl}$ dalam berbagai konsentrasi (0,5\%, 1\%,1,5\%,2\%,3\%, dan 4\%) untuk balok gipsum yang dijadikan variabel terikat. $\mathrm{NaCl}$ adalah Natrium Klorida yang diperoleh dari pasaran berupa garam dapur yang digunakan sehari-hari.

\section{HASIL PENELITIAN}

Balok gipsum dari dental plaster yang setelah 1 jam didiamkan. Hasilnya dapat telah mengeras dikeluarkan dari cetakan dilihat pada gambar 3 di bawah ini:

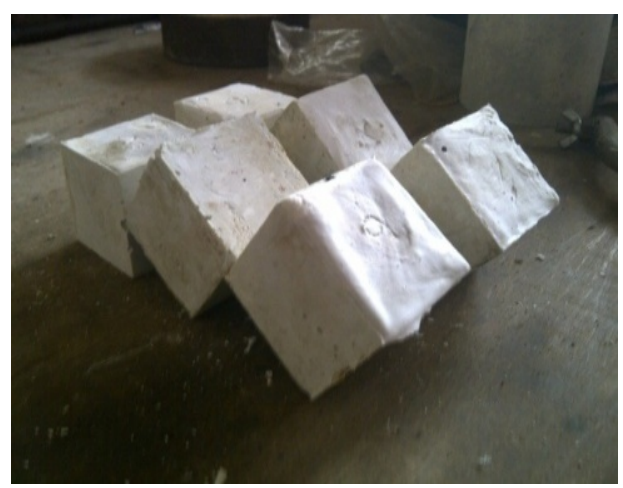

Gambar 3. Balok gipsum dental plaster yang telah dikeluarkan dari cetakan.

Pengukuran kekuatan kompresi dilakukan dengan menggunakan alat uji kompresi (control digital) yang angka atau nilainya langsung bisa terlihat pada skala yang tertera pada alat uji kompresi seperti gambar 4 berikut ini:

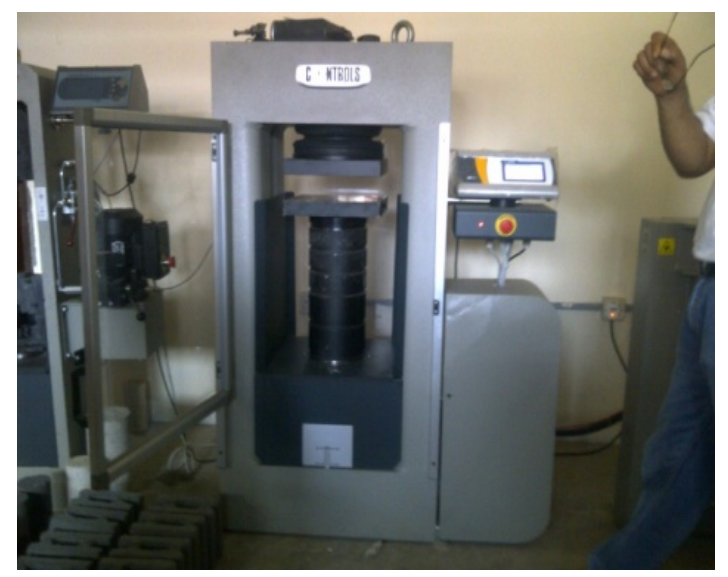

Gambar 4. Alat Uji Kompresi 
Hasil uji kekuatan kompresi pada balok gipsum dental plaster tanpa penambahan larutan $\mathrm{NaCl}$, yang dihitung dalam satuan Mega Pascal (MPa) dapat dilihat pada tabel 1 berikut ini:

Tabel 1. Distribusi hasil uji kekuatan kompresi balok gipsum dental plaster tanpa penambahan $\mathrm{NaCl}$ dalam satuan Mega Pascal (MPa)

\begin{tabular}{|c|c|c|c|c|}
\hline \multirow{2}{*}{$\begin{array}{c}\text { Aquades } \\
\text { (kontrol) }\end{array}$} & $\begin{array}{c}|c| \\
\text { Balok } \\
\text { gipsum 1 }\end{array}$ & $\begin{array}{c}\text { Balok } \\
\text { gipsum 2 }\end{array}$ & $\begin{array}{c}\text { Balok } \\
\text { gipsum 3 }\end{array}$ & $\begin{array}{c}\text { Hasil rata-rata } \\
\text { (MPa) }\end{array}$ \\
\cline { 2 - 4 } & 8,99 & 8,45 & 8,45 & 8,63 \\
\hline
\end{tabular}

Data pada tabel 1. Menunjukkan bahwa hasil pengukuran uji kekuatan kompresi pada balok gipsum dental plaster tanpa penambahan larutan $\mathrm{NaCl}$,yaitu pada balok gipsum pertama didapatkan kekuatan kompresi mencapai 8,99 MPa; hasil pada balok gipsum dental plaster kedua pada gambar 5 berikut ini.

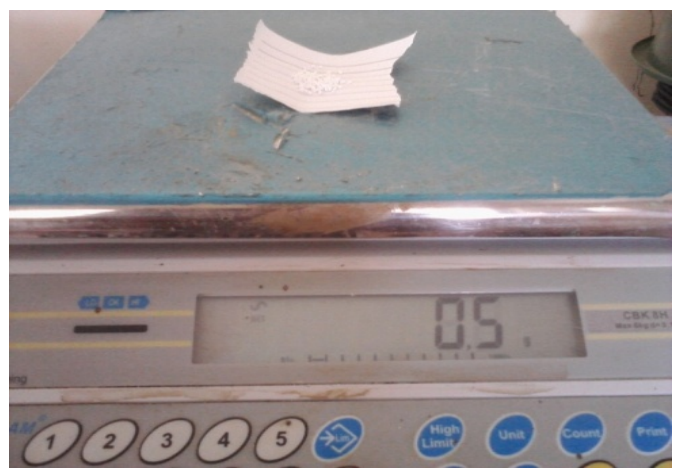

Gambar 5. Hasil pengukuran $\mathrm{NaCl}$ 0,5 gram

Hasil uji kekuatan kompresi pada balok gipsum dental plaster dengan penambahan larutan $\mathrm{NaCl}$ 0,5\%, yang dihitung dalam satuan MPa dapat dilihat pada tabel 2 berikut ini: 
Tabel 2. Distribusi hasil uji kekuatan kompresi balok gipsum dental plaster dengan penambahan larutan $\mathrm{NaCl}$ pada konsentrasi $0,5 \%$ dalam satuan Mega Pascal (MPa)

\begin{tabular}{|c|c|c|c|c|}
\hline \multirow{2}{*}{$\begin{array}{c}\text { Konsentrasi larutan } \\
\mathrm{NaCl}\end{array}$} & \multicolumn{2}{|c|}{ Hasil Uji Kekuatan kompresi (MPa) } & Hasil rata-rata \\
\cline { 2 - 4 } & $\begin{array}{c}\text { Balok } \\
\text { gipsum 1 }\end{array}$ & $\begin{array}{c}\text { Balok } \\
\text { gipsum 2 }\end{array}$ & $\begin{array}{c}\text { Balok } \\
\text { gipsum 3 }\end{array}$ & \\
\hline $\mathrm{NaCl} 0,5 \%$ & 6,34 & 7,24 & 7,61 & 6,90 \\
\hline
\end{tabular}

Data pada tabel 2 menunjukkan bahwa hasil pengukuran uji kekuatan kompresi pada balok gipsum dental plaster dengan penambahan larutan $\mathrm{NaCl} 0,5 \%$, menunjukkan hasil sebagai berikut: Balok gipsum pertama didapatkan kekuatan kompresi mencapai 6,34 MPa; hasil pada balok gipsum dental plaster kedua menunjukkan tingkat kekuatan kompresi mencapai 7,24 MPa ; sedangkan pada balok gipsum dental plaster ketiga kekuatan kompresi mencapai 7,61 $\mathrm{MPa}$ (Gambar 6).

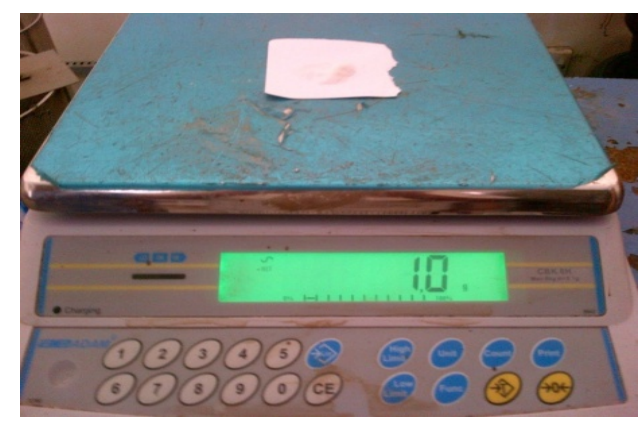

Gambar 6. Hasil pengukuran $\mathrm{NaCl} 1$ gram

Hasil uji kekuatan kompresi pada balok gipsum dental plaster dengan penambahan larutan $\mathrm{NaCl} 1 \%$, yang dihitung dalam satuan MPa dapat dilihat pada Tabel 3 . Data pada Tabel 3 menunjukkan bahwa hasil pengukuran uji kekuatan kompresi pada balok gipsum dental plaster dengan penambahan larutan $\mathrm{NaCl} 1 \%$, yaitu pada balok gipsum pertama didapatkan kekuatan kompresi mencapai 6,57 MPa; hasil pada balok gipsum dental plaster kedua menunjukkan tingkat kekuatan kompresi mencapai 6,92 MPa ; sedangkan pada balok gipsum dental plaster ketiga kekuatan kompresi mencapai 6,90 MPa. Hasil rata-rata uji kekuatan kompresi balok gipsum dental plaster sebesar 6,90 MPa. 
Tabel 3. Distribusi hasil uji kekuatan kompresi balok gipsum dental plaster dengan penambahan larutan $\mathrm{NaCl}$ pada konsentrasi $1 \%$ dalam satuan Mega Pascal (MPa)

\begin{tabular}{|c|c|c|c|c|}
\hline \multirow{2}{*}{$\begin{array}{c}\text { Konsentrasi } \\
\text { larutan NaCl }\end{array}$} & \multicolumn{2}{|c|}{ Hasil Uji Kekuatan kompresi (MPa) } & \multirow{2}{*}{$\begin{array}{c}\text { Hasil rata-rata } \\
\text { (MPa) }\end{array}$} \\
\cline { 2 - 4 } & $\begin{array}{c}\text { Balok } \\
\text { gipsum 1 }\end{array}$ & $\begin{array}{c}\text { Balok } \\
\text { gipsum 2 }\end{array}$ & $\begin{array}{c}\text { Balok } \\
\text { gipsum 3 }\end{array}$ & \\
\hline $\mathrm{NaCl} 1 \%$ & 6,57 & 6,92 & 7,23 & 6,90 \\
\hline
\end{tabular}

Hasil pengukuran berat $\mathrm{NaCl}, 51$ gram untuk pembuatan larutan $\mathrm{NaCl}$ 1,5\% dapat dilihat pada gambar 7 berikut ini:

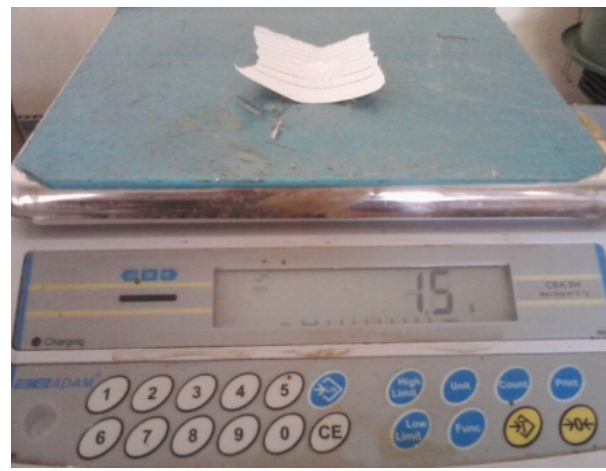

Gambar 7. Hasil pengukuran $\mathrm{NaCl} 1,5$ gram

Hasil uji kekuatan kompresi pada balok gipsum dental plaster dengan penambahan larutan $\mathrm{NaCl} 1,5 \%$, yang dihitung dalam satuan MPa dapat dilihat pada tabel 7 berikut ini:

Tabel 4. Distribusi hasil uji kekuatan kompresi balok gipsum dental plaster dengan penambahan larutan $\mathrm{NaCl}$ pada konsentrasi 1,5\% dalam satuan Mega Pascal (MPa)

\begin{tabular}{|c|c|c|c|c|}
\hline \multirow{2}{*}{$\begin{array}{l}\text { Konsentrasi } \\
\text { larutan } \mathrm{NaCl}\end{array}$} & \multicolumn{3}{|c|}{ Hasil Uji Kekuatan kompresi (MPa) } & \multirow{2}{*}{$\begin{array}{c}\text { Hasil rata-rata } \\
(\mathrm{MPa})\end{array}$} \\
\hline & $\begin{array}{c}\text { Balok } \\
\text { gipsum } 1\end{array}$ & $\begin{array}{c}\text { Balok } \\
\text { gipsum } 2\end{array}$ & $\begin{array}{c}\text { Balok } \\
\text { gipsum } 3\end{array}$ & \\
\hline $\mathrm{NaCl} 1,5 \%$ & 10,4 & 12,4 & 13,89 & 12,23 \\
\hline
\end{tabular}

Data pada tabel 4. Menunjukkan bahwa hasil pengukuran uji kekuatan kompresi pada balok gipsum dental plaster dengan penambahan larutan $\mathrm{NaCl}$ 1,5\%, yaitu pada balok gipsum pertama didapatkan kekuatan kompresi mencapai 10,4 MPa; hasil pada 
balok gipsum dental plaster

kedua menunjukkan tingkat

kekuatan kompresi mencapai 12,4

MPa ; sedangkan pada balok

gipsum dental plaster ketiga kekuatan kompresi mencapai 13,89 MPa. Hasil rata-rata uji kekuatan kompresi balok gipsum dental plaster sebesar 12,23 MPa.

Hasil pengukuran berat $\mathrm{NaCl} 2$ gram untuk pembuatan larutan $\mathrm{NaCl} 2 \%$ dapat dilihat pada gambar 8 berikut ini:

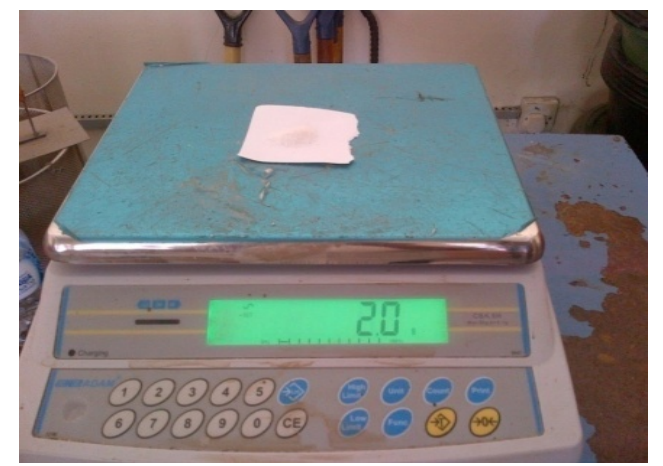

Gambar 8. Hasil pengukuran $\mathrm{NaCl} 2$ gram

Hasil uji kekuatan kompresi pada balok gipsum dental plaster dengan penambahan larutan $\mathrm{NaCl} 2 \%$, yang dihitung dalam satuan $\quad \mathrm{MPa}$ dapat dilihat pada tabel 7 berikut ini:

Tabel 7. Distribusi hasil uji kekuatan kompresi balok gipsum dental plaster dengan penambahan larutan $\mathrm{NaCl}$ pada konsentrasi $2 \%$ dalam satuan Mega Pascal (MPa)

\begin{tabular}{|c|c|c|c|c|}
\hline \multirow{2}{*}{$\begin{array}{c}\text { Konsentrasi } \\
\text { larutan NaCl }\end{array}$} & \multicolumn{2}{|c|}{ Hasil Uji Kekuatan kompresi (MPa) } & \multirow{2}{*}{$\begin{array}{c}\text { Hasil rata-rata } \\
\text { (MPa) }\end{array}$} \\
\cline { 2 - 4 } & $\begin{array}{c}\text { Balok } \\
\text { gipsum 1 }\end{array}$ & $\begin{array}{c}\text { Balok } \\
\text { gipsum 2 }\end{array}$ & $\begin{array}{c}\text { Balok } \\
\text { gipsum 3 }\end{array}$ & \\
\hline $\mathrm{NaCl} \mathrm{2 \%}$ & 9,80 & 10,19 & 10,19 & 10,06 \\
\hline
\end{tabular}

Data pada tabel 5. Menunjukkan

bahwa hasil pengukuran uji kekuatan kompresi pada balok gipsum dental plaster dengan penambahan larutan $\mathrm{NaCl} 2 \%$, yaitu pada balok gipsum pertama didapatkan kekuatan kompresi mencapai 9,80 $\mathrm{MPa}$; hasil pada balok gipsum dental plaster kedua menunjukkan tingkat kekuatan kompresi mencapai 10,19 MPa; sedangkan pada balok 
gipsum dental plaster ketiga kekuatan kompresi balok gipsum kekuatan kompresi mencapai dental plaster sebesar 10,06 MPa. 10,19 MPa. Hasil rata-rata uji

Hasil pengukuran berat $\mathrm{NaCl} 3$ gram untuk pembuatan larutan $\mathrm{NaCl} 3 \%$ dapat dilihat pada gambar 9 berikut ini:

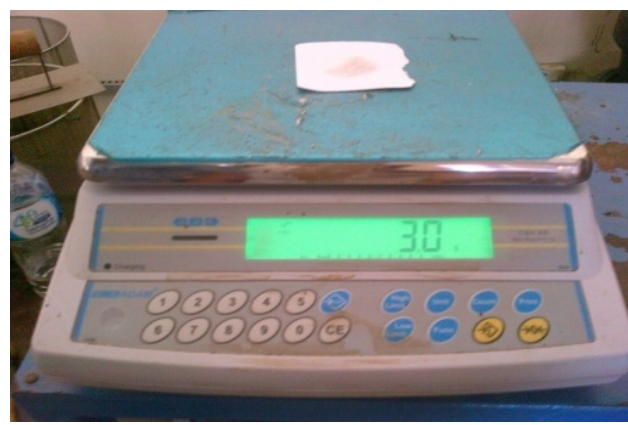

Gambar 9. Hasil pengukuran $\mathrm{NaCl} 3$ gram

Hasil uji kekuatan kompresi pada balok gipsum dental plaster dengan penambahan larutan $\mathrm{NaCl} 3 \%$, yang dihitung dalam satuan MPa dapat dilihat pada tabel 6 berikut ini:

Tabel 6. Distribusi hasil uji kekuatan kompresi balok gipsum dental plaster dengan penambahan larutan $\mathrm{NaCl}$ pada konsentrasi $3 \%$ dalam satuan Mega Pascal (MPa)

\begin{tabular}{|c|c|c|c|c|}
\hline \multirow{2}{*}{$\begin{array}{c}\text { Konsentrasi } \\
\text { larutan NaCl }\end{array}$} & \multicolumn{2}{|c|}{ Hasil Uji Kekuatan kompresi (MPa) } & \multirow{2}{*}{$\begin{array}{c}\text { Hasil rata-rata } \\
\text { (MPa) }\end{array}$} \\
\cline { 2 - 4 } & $\begin{array}{c}\text { Balok } \\
\text { gipsum 1 }\end{array}$ & $\begin{array}{c}\text { Balok } \\
\text { gipsum 2 }\end{array}$ & $\begin{array}{c}\text { Balok } \\
\text { gipsum 3 }\end{array}$ & \\
\hline $\mathrm{NaCl} \mathrm{3 \%}$ & 6,92 & 6,10 & 5,88 & 6,33 \\
\hline
\end{tabular}

Data pada tabel 6 menunjukkan bahwa hasil pengukuran uji kekuatan kompresi pada balok gipsum dental plaster dengan penambahan larutan $\mathrm{NaCl} 3 \%$, yaitu pada balok gipsum pertama didapatkan kekuatan kompresi mencapai 6,92 MPa; hasil pada balok gipsum dental plaster kedua menunjukkan tingkat kekuatan kompresi mencapai 6,10 $\mathrm{MPa}$; sedangkan pada balok gipsum dental plaster ketiga kekuatan kompresi mencapai 5,88 MPa. Hasil rata-rata uji kekuatan 
kompresi balok gipsum dental plaster sebesar 6,33 $\mathrm{MPa}$.

Hasil pengukuran berat $\mathrm{NaCl} 4$ gram untuk pembuatan larutan $\mathrm{NaCl} 4 \%$ dapat dilihat pada gambar 9 berikut ini:

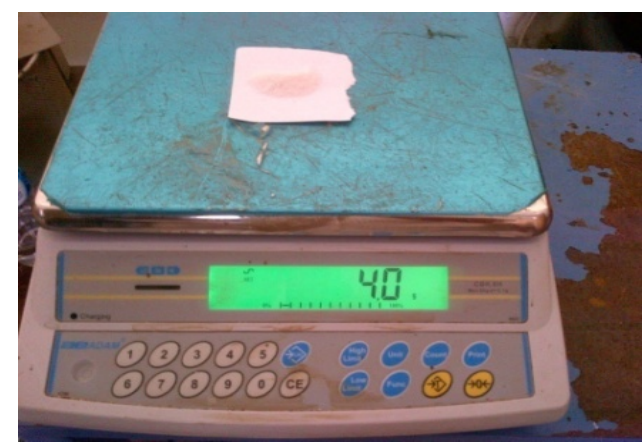

Gambar 9. Hasil pengukuran $\mathrm{NaCl} 4$ gram

Hasil uji kekuatan kompresi pada balok gipsum dental plaster dengan penambahan larutan $\mathrm{NaCl} 4 \%$, yang dihitung dalam satuan $\mathrm{MPa}$ dapat dilihat pada tabel 7 berikut ini:

Tabel 7. Distribusi hasil uji kekuatan kompresi balok gipsum dental plaster dengan penambahan larutan $\mathrm{NaCl}$ pada konsentrasi $4 \%$ dalam satuan Mega Pascal (MPa)

\begin{tabular}{|c|c|c|c|c|}
\hline \multirow{2}{*}{$\begin{array}{c}\text { Konsentrasi } \\
\text { larutan NaCl }\end{array}$} & \multicolumn{2}{|c|}{ Hasil Uji Kekuatan kompresi (MPa) } & \multirow{2}{*}{$\begin{array}{c}\text { Hasil rata-rata } \\
\text { (MPa) }\end{array}$} \\
\cline { 2 - 4 } & $\begin{array}{c}\text { Balok } \\
\text { gipsum 1 }\end{array}$ & $\begin{array}{c}\text { Balok } \\
\text { gipsum 2 }\end{array}$ & $\begin{array}{c}\text { Balok } \\
\text { gipsum 3 }\end{array}$ & \\
\hline $\mathrm{NaCl} 4 \%$ & 5,60 & 3,65 & 4,02 & 4,42 \\
\hline
\end{tabular}

Data pada tabel 7. Menunjukkan

bahwa hasil pengukuran uji

kekuatan kompresi pada balok

gipsum dental plaster dengan

penambahan larutan $\mathrm{NaCl} 4 \%$,

yaitu sebesar 5,60 MPa pada balok gipsum pertama; 3,65 MPa hasil pada balok gipsum dental plaster kedua; sebesar 4,02 $\mathrm{MPa}$ pada balok gipsum dental plaster ketiga dan hasil rata-rata uji kekuatan kompresi sebesar 4,42 MPa. 
Hasil rata-rata uji kekuatan kompresi balok gipsum dental plaster dengan variasi konsentrasi larutan $\mathrm{NaCl}$ 0,5\%; 1\%; 1,5\%; 2\%; 3\%; 4\% dalam satuan MPa (Tabel 8).

Tabel 8. Distribusi hasil rata-rata pengukuran kekuatan kompresi balok gipsum dental plaster dalam satuan Mega Pascal (MPa)

\begin{tabular}{|c|c|}
\hline \multirow{2}{*}{$\begin{array}{c}\text { Konsentrasi Larutan } \\
\mathrm{NaCl}\end{array}$} & Hasil Uji kekuatan kompresi (MPa) \\
\cline { 2 - 2 } & Hasil rata-rata (MPa) \\
\hline $\mathrm{NaCl} \mathrm{0,5 \%}$ & 7,06 \\
\hline $\mathrm{NaCl} 1 \%$ & 6,90 \\
\hline $\mathrm{NaCl} \mathrm{1,5}$ & 12,2 \\
\hline $\mathrm{NaCl} \mathrm{2 \%}$ & 10,0 \\
\hline $\mathrm{NaCl} \mathrm{3 \%}$ & 6,33 \\
\hline $\mathrm{NaCl} 4 \%$ & 4,42 \\
\hline
\end{tabular}

Data pada tabel 8 menunjukkan

bahwa hasil rata-rata pengukuran kekuatan kompresi pada balok gipsum dental plaster dengan penambahan larutan $\mathrm{NaCl}$ pada konsentrasi $0,5 \%$ sebesar 7,06 MPa, konsentrasi $1 \%$ sebesar
6,90 MPa, konsentrasi 1,5\% sebesar 12,23 MPa, konsentrasi 2\% sebesar 10,06 $\mathrm{MPa}$, konsentrasi $3 \%$ sebesar 6,33 MPa, dan konsentrasi 4\% sebesar 4,42 MPa.

\section{BAHASAN}

Pada penelitian ini dilakukan penambahan $\mathrm{NaCl}$ (garam dapur) untuk pembuatan larutan $\mathrm{NaCl}$ dalam berbagai konsentrasi yang digunakan untuk membuat balok gipsum dental plaster yang diuji kekuatan kompresinya. Hasil yang diperoleh menunjukkan turunnya kekuatan kompresi pada penggunaan larutan $\mathrm{NaCl}$ 0,5\% bila dibandingkan

dengan kontrol. Namun bila dibandingkan dengan penggunaan larutan $\mathrm{NaCl} 1 \%$ hingga larutan $\mathrm{NaCl} 1,5 \%$, kekuatan tekannya menunjukkan trend menaik. Turunnya kekuatan kompresi mungkin karena pengaruh penambahan $\mathrm{NaCl}$. $\mathrm{NaCl}$ di sini berfungsi sebagai aselerator yaitu menyebabkan waktu pengerasan 
(setting time) lebih cepat, sehingga mungkin saja proses manipulasi belum terjadi secara merata namun kristalisasi sudah terjadi pada sebagian besar campuran gipsum dental plaster. Hal ini dapat menyebabkan kekerasan gipsum dental plaster menurun akibat tidak meratanya kristalisasi yang terjadi. Di samping itu mungkin juga dipengaruhi oleh suhu ruangan. Suhu dapat memengaruhi setting time menjadi lebih lambat. Suhu yang rendah menyebabkan campuran gipsum dental plaster lama mengeras atau menghambat proses kristalisasi. Hal lainnya yang berpengaruh yaitu kemurnian bubuk dental plaster. Dalam hal ini kemurnian adukan gipsum dental plaster dipengaruhi oleh adanya penambahan $\mathrm{NaCl}$ serta ketidakmurnian $\mathrm{NaCl}$ yang digunakan. Seperti diketahui $\mathrm{NaCl}$ yang digunakan dalam penelitian ini bukan $\mathrm{NaCl}$ murni, namun berupa garam dapur yang ada di pasaran. Biasanya bubuk garam ini sudah mengandung beberapa unsur kimia lainnya selain $\mathrm{NaCl}$. Seperti contoh garam dapur standar SNI yang mengandung $\mathrm{NaCl}$ 94,9\%; dan kandungan lainnya berupa air $\left(\mathrm{H}_{2} \mathrm{O}\right)$; yodium; $\mathrm{Fe}_{2} \mathrm{O}_{3} ; \mathrm{Ca}$ dan $\mathrm{Mg} ; \mathrm{SO}_{4}$ serta bagian yang tidak larut dalam air. Kandungan-kandungan ini menye-babkan ketidakmurnian campuran adukan gipsum dental plaster yang akan memengaruhi tingkat kekerasannya.

Adanya trend menaik pada kekuatan kompresi gipsum dental plaster pada penggunaan larutan $\mathrm{NaCl}$ 1\% hingga 1,5\% mungkin diakibatkan karena pemakaian elektron bersama dari bubuk hemihidrat dental plaster dan $\mathrm{NaCl}$ yang ditambahkan, sehingga terjadi ikatan-ikatan kimia yang stabil yang menyebabkan kekerasan gipsum dental plaster bertambah dan meningkatkan kekuatan kompresinya. Faktor lainnya yang mungkin berpengaruh terhadap peningkatan kekuatan kompresi gipsum dental plaster, yakni waktu dan kecepatan pengadukan, suhu dan tekanan atmosfir, alat dan bahan yang digunakan, hal-hal ini sangat penting diperhatikan karena dapat berpengaruh terhadap kekuatan tekan balok gipsum dental plaster tersebut.

Bila dibandingkan dengan penelitian sejenis yang dilakukan sebelumnya, terdapat perbedaan hasil yang diperoleh. Hasil yang diperoleh dalam penelitian yang dilakukan oleh Maria Howarto (2012), penambahan 
$\mathrm{NaCl}$ dalam adukan gipsum dental plaster menunjukkan peningkatan pada konsentrasi larutan $\mathrm{NaCl}$ 1\% dibandingkan kontrol, selanjutnya menunjukkan trend menurun pada konsentrasi larutan $\mathrm{NaCl} 2 \%$; 3\%; 5\%; 10\% dan 30\%. Hal ini agak berbeda dengan hasil penelitian, dimana hasil yang diperoleh menunjukkan peningkatan kekuatan kompresi dari kontrol pada konsentrasi $0,5 \%$. Selanjutnya pada konsentrasi 0,5\% hingga konsentrasi 1,5\% memperlihatkan trend menaik dan kembali menurun pada konsentrasi 2\% hingga 4\%. Secara umum perbedaan perolehan hasil mungkin disebabkan oleh karena penggunaan bahan campuran $\mathrm{NaCl}$ yang berbeda, dimana pada penelitian sebelumnya digunakan $\mathrm{NaCl}$ murni sedangkan pada penelitian yang dilakukan menggunakan $\mathrm{NaCl}$ berupa garam dapur yang banyak mengandung unsur-unsur kimia lainnya. Keberadaan unsur-unsur ini memengaruhi kemurnian campuran gipsum dental plaster yang dapat berpengaruh pada kekerasannya. Perbedaan lainnya bisa juga disebabkan karena perbedaan jenis atau merek dental plaster yang digunakan, sedangkan penelitian yang dilakukan menggunakan dental plaster merek super type 6000. Pada penelitian yang dilakukan sebelumnya menggunakan alat uji kekuatan kompresi manual. Dalam wawancara yang dilakukan dengan petugas laboratorium teknik dimana penelitian ini dilakukan, diperoleh informasi bahwa pada penelitian sebelumnya skala hasil uji kekuatan kompresi sulit terbaca. Dengan demikian hasil yang diperoleh tidak begitu akurat. Penelitian yang dilakukan selanjutnya menggunakan alat yang berbeda, yakni alat uji kekuatan kompresi digital. Hal ini memungkinkan hasil uji terbaca dengan jelas, dan lebih akurat dibanding hasil terdahulu oleh Maria Howarto. Kondisi lainnya yang mungkin juga memengaruhi, yakni pengadukan yang tidak teratur dan homogen dapat menyebabkan banyaknya udara yang terjebak. Apabila udara ini tidak dihilangkan maka dapat menyebabkan kelemahan pada balok gipsum dental plaster akibat porositas yang terbentuk setelah dental plaster mengeras. Oleh karena itu pada manipulasi dental plaster penggunaan vibrator sangat diperlukan. Faktor suhu juga memiliki peran menentukan pada kekerasan atau kekuatan kompresi 
gipsum dental plaster. Perbedaan hasil yang diperoleh dengan penelitian terdahulu mungkin juga disebabkan oleh perbedaan suhu ruangan saat penelitian dilakukan. Efek suhu yang berbeda akan memengaruhi setting time, dimana pada suhu yang rendah setting time akan lebih panjang dan kekerasan atau kekuatan kompresi gipsum dental plaster akan berkurang. Kekuatan kompresi dental plaster kering 2 (dua) kali lebih kuat dari kekuatan basahnya, karena kekerasan dari produk gipsum terjadi jika air keluar dan kristal-kristal gipsum yang halus mengendap yang menghasilkan pengikatan kristal-

\section{SIMPULAN}

Terjadi perubahan kekuatan kompresi pada dental plaster yang dicampur dengan $\mathrm{NaCl}$ dalam berbagai variasi konsentrasi. Peningkatan kekuatan kompresi maksimal terhadap dental plaster terjadi pada pencampuran menggunakan larutan $\mathrm{NaCl}$ 1,5\%.

\section{SARAN}

Dapat mempertimbangkan penambahan $\mathrm{NaCl}$ pada saat pencampuran dental plaster untuk keperluan pembuatan

\section{DAFTAR PUSTAKA}

1. Anusavice KJ. Buku ajar ilmu bahan kedokteran gigi, ed. 10. Jakarta: EGC; 2004: h; 155-75. kristal gipsum menjadi lebih besar. Apabila masih terdapat kelebihan air akibat terhambatnya proses penguapan karena suhu yang rendah, mengakibatkan kristal-kristal gipsum menjadi terlarut dan pengikatannya menjadi lemah. Dari hasil penelitian yang dilakukan ternyata dengan penambahan $\mathrm{NaCl}$ dalam pencampuran adukan dental plaster melalui larutan $\mathrm{NaCl}$ dalam berbagai konsentrasi menunjukkan adanya perubahan kekuatan kompresi dental plaster. Kekuatan kompresi terbesar diperoleh pada pencampuran adukan dental plaster menggunakan larutan $\mathrm{NaCl}$ 1,5\%.

model rahang dan lain-lain bagi keperluan perawatan dalam bidang Prostodonsia maupun Ortodonsia sebagai bahan alternatif pada kondisi darurat dimana dibutuhkan bahan gipsum yang memiliki kekuatan yang tinggi dan kekerasan permukaan yang memadai untuk keperluan perawatan.Perlu dilakukan penelitian sejenis dengan melakukan pengendalian pada factor-faktor yang dapat memengaruhi kekerasan atau kekuatan kompresi dental plaster, sehingga dapat diperoleh hasil yang lebih akurat.

2. Craig RG, Powers JM, Wataha JC. Dental materials, $8^{\text {th }}$ ed. India: Mosby; 2005: p; 199-215. 
3. Anusavice KJ. Philips'science of dental materials, $11^{\text {th }}$ ed. India: Saunders; 2004: p; 255-77

4. Mahler DB, Ady AB, Fairhurst CW. Gypsum objective. 2010

5. Kuntze RA: The Chemistry and Technology of Gypsum. Philadelphia, American Sociaty for Testing and Meterials, STP 816,2002

6. Anusavice KJ. Philips'science of dental materials, $11^{\text {th }}$ ed. India: Saunders; 2004: p; 255-77

7. Anusavice KJ. Philips'science of dental materials, $11^{\text {th }}$ ed. India: Saunders; 2004: p; 255-77

8. Soratur SH. Essential of dental materials. New Delhi: Jaypee; 2007. p.133-143.

9. Bayne SC. Hill C. Dental anatomi and morphology. 2005

10. Manappallil JJ. Basic dental material. Foreword by V surendra Shetty. New delhi, India: Jaypee; 2003.p.82-97

11. Koudi MS, Sanjayagouda BP. Dental materials prep manual for undergraduates. $1^{\text {st }}$ ed. New Dehli; Elsevier: 2007.p.47-54

12. Chandra S, Chandra Sh, Chandra R. A text book of dental materials with multiple choice question. Foreword Surush Chandra. New delhi, India: Jaypee; 2007.p.36-47
13. Wisnumurti, Ristinah, Puteri YA. Pengaruh penggunaan akselerator megaset merah dibawah dosis optimal terhadap kuat tekan beton dengan berbagai variasi umur beton. Jurnal rekayasa sipil, vol1. Malang. 2007

14. Kurlansky M. Salt: A world history. Walker publishing company. 2002

15. Hussain S. Textbook of dental materials. Foreword. MF Baig, NM Veeraiyan. $1^{\text {st }}$ ed. New Dehli, India: Jaypee; 2004.p.38-43.

16. Suyatno. 2010. Menghitung besar sampel penelitian kesehatan masyarakat. Serial online (diakses 24 Oktober 2013). Available from URL:

http://suyatno.blog.undip.ac.id/files/201 0/05/menghitung-besar-sampelpenelitian.pdf

17. Fraunhofer JAV. Dental Material at a glance. Hongkong: Wiley-blackwell; 2010.p.8-9.

18. Ramachandran VS. Concrete admixtures handbook. $2^{\text {nd }}$ ed. USA; Noyes publications: 1995.p.1087-9.

19. Taylor HFW. Cement chemistry. $2^{\text {nd }}$ ed. London; Thomas Telford: 2003.p.347.

20. Jorgensen KD: Studies on the setting of plaster of paris. Odont T 305, 1994 